\title{
Computerized diagnostic for the fuel injection control system
}

\author{
The purpose of the study is to carry out the experimental tests for the propulsion unit of the selected passenger car i.e. \\ Skoda Felicia 1.3 MPI provided with Simos 2P system (manufactured by Siemens). The tests were carried out by means \\ of an appropriate measuring equipment, among others AOC1K oscilloscope (digital recorder integrated with PC by \\ means of RS232 interface) and a personal computer. \\ The measurements of signals on the contacts of the electronic control device encompass the measuring procedures for \\ individual signals, in accordance with the contact symbols: the camshaft position sensor, the engine speed sensor, the \\ lambda probe, the pressure sensor, the throttle position sensor, the idle speed control actuator, the knock sensor. \\ In some cases it is impossible to confirm the standard codes by the execution of diagnostic tests of the modern control \\ system of ZI combustion engine, using the Simos $2 P$ system.
}

Key words: car diagnostics, knock sensor, throttle actuator, pressure sensor, oxygen sensor, speed sensor

\section{Komputerowa diagnostyka układu sterowania wtryskiem paliwa}

\begin{abstract}
$W$ artykule przedstawiono badania eksperymentalne systemu sterowania jednostka napędowa samochodu osobowego na przyktadzie pojazdu marki Skoda Felicia 1.3 MPI, majacego system Simos 2P firmy Siemens. Badania przeprowadzano z użciem m.in. oscyloskopu AOC1K (rejestratora cyfrowego, wspótpracujacego z komputerem PC przez interfejs RS232) i komputera PC.

Pomiary sygnatów na stykach elektronicznego urządzenia sterującego obejmuja procedury pomiarowe dla poszczególnych sygnałów: czujnika położenia i prędkości obrotowej wału korbowego, sondy lambda, czujnika ciśnienia zasysanego powietrza, czujnika położenia przepustnicy, regulatora biegu jałowego oraz czujnika spalania stukowego.

Wyniki badań układu sterowania silnika spalinowego ZI, na przykładzie systemu Simos 2P, nie zawsze potwierdzaja zgodność z wzorcowymi kodami.
\end{abstract}

Słowa kluczowe: diagnostyka pojazdowa, czujnik spalania stukowego, czujnik ciśnienia, czujnik tlenu

\section{General}

The use of the achievements in the scope of electronics, automatic control engineering and information technology appear to be an essential step in the automotive sector development stimulating the analyses of environment protection requirements, improving the road traffic safety and increasing the comfort of travel. In order to meet the requirements in the scope of modern equipment of the vehicles, it is necessary to promptly analyse the occurred situation (within a part of second), to elaborate the conclusions and to ensure the correct reaction, sometimes even against the actions performed by the driver, particularly in case of safety systems i.e. ABS, ESP increasing the level of safety on crowded roads which are not adapted to the design solutions of modern vehicles.

The electric and electronic equipment must be provided with power supply and must enable the information exchange between its individual units. Owing to the requirements in the scope information exchange in the modern vehicles, other types of airborne networks cabling had to be introduced - multiplex systems using among others optic fibres. The signals are adequately coded and transmitted in accordance with established data transmission protocols. The determination of potential defects and their localisation is generally limited to data reading via diagnostic interface between

\section{Wstęp}

Istotnym krokiem w rozwoju motoryzacji okazało się wykorzystanie osiągnięć z dziedziny elektroniki, automatyki i informatyki. Spowodowało to, że zaczęto realizować wymagania dotyczące ochrony środowiska, poprawiając bezpieczeństwo ruchu i zwiększając komfort podróżowania. Wymagania dotyczące współczesnego wyposażenia pojazdów wymuszają konieczność błyskawicznej analizy zaistniałej sytuacji, wypracowania wniosków i odpowiedniego zareagowania, niejednokrotnie wbrew czynnościom wykonywanym przez kierowcę. Dotyczy to szczególnie układów bezpieczeństwa, takich jak ABS, ESP, podnoszących bezpieczeństwo na zatłoczonych i nieprzystosowanych do konstrukcji współczesnych pojazdów drogach.

Wyposażenie elektryczne i elektroniczne musi być zasilane i musi wymieniać między sobą informacje. Wymagania dotyczące przesyłu informacji we współczesnych pojazdach wymusiły wprowadzenie innego rodzaju okablowania sieci pokładowych - instalacje multipleksowe, wykorzystujące między innymi światłowody. Sygnały są odpowiednio kodowane i przesyłane zgodnie z przyjętymi protokółami transmisji danych. Dzięki zdolności systemu do szczegółowego dokumentowania i zapamiętywania wadliwego działania przez autodiagnozę, ewentualne określanie i lokalizowanie 
the service device and central control module, because the system enables the detailed documentation and saving any defective operation by automatic diagnostic functions.

However sometimes it is impossible to confirm the conformity with the standard codes by the execution of diagnostic tests of the modern control system of ZI combustion engine, using the Simos 2P system (manufactured by Siemens).

\section{Testing of the fuel injection control system}

The tests executed for SIMOS 2P fuel injection and ignition system encompassed the following scope:

- checking of hydraulic connections in fuel system and checking of electric connections in the engine control system;

- measurements of the fuel flow rate and fuel pressure for the fuel supplied to the injectors;

- determination of electric parameters on the "control device edge" with ignition OFF, ignition ON and operating engine;

- execution of oscilloscope measurements for the sensors and actuators generating the signals changing dynamically in course of engine operation.

The tests were carried out by means of an appropriate measuring equipment, among others $\mathrm{AOC} 1 \mathrm{~K}$ oscilloscope (digital recorder integrated with PC by means of RS232 interface) and a personal computer.

The following vehicles provided with Simos 2P (Siemens) system were tested:

1. Skoda Felicia 1.3 MPI hatchback, manufacturing year 1998; mileage - $220000 \mathrm{~km}$ including $100000 \mathrm{~km}$ using lead-free petrol LO 95 and 120 000km using LPG; maintenance and servicing in accordance with the manufacturer's requirements;

2. Skoda Felicia 1,3 MPI pickup, manufacturing year 1997; mileage - $70000 \mathrm{~km}$ - using lead-free petrol LO 95; maintenance and servicing in accordance with the manufacturer's requirements. A physical damage of the fuel injector and increased exhaust gases toxicity have been found in course of operation.

Prior to testing the sensors and actuators in the engine operation control system, the conductors shall visually inspected (for potential wearing or breaks) and evaluated for their technical condition. The inspection of the connectors connecting the wire assemblies with the devices is also required in order to avoid any faults to frame, fault to positive or between the wires included in the same wire assembly. Particular attention should be paid to contaminations deposited on the connectors which may result in increased resistance on the joint or complete circuit discontinuity.

It is extremely important to check the fuel system for correct operation i.e. the inspection of fuel pump relay and fuel pump. The hydraulic elements of the system must be checked for leak free and unobstructed condition.

The measurements of signals on the contacts of the electronic control device (Simos 2P) (ECM - engine control module) encompass the measuring procedures for individual signals, in accordance with the contact symbols. The meas- uszkodzeń ogranicza się na ogół do odczytania danych przez złącze diagnostyczne między przyrządem serwisowym a centralnym modułem sterującym.

Celem pracy było przeprowadzenie badań diagnostycznych współczesnego układu sterowania silnika spalinowego ZI, na przykładzie systemu Simos 2P (firmy Siemens), pojazdu marki Skoda Felicia 1.3 MPI.

\section{Badania układu sterowania wtryskiem paliwa}

Badania układu sterowania wtryskiem paliwa i zapłonem Simos 2P obejmowały:

- sprawdzenie połączeń hydraulicznych układu paliwowego oraz połączeń elektrycznych układu sterowania silnikiem,

- wykonanie pomiarów wydatku i ciśnienia paliwa dostarczanego do wtryskiwaczy,

- ustalenie wartości wielkości elektrycznych na „krawędziówce urządzenia sterującego" podczas wyłączonego zapłonu, włączonego zapłonu i pracy silnika,

- przeprowadzenie pomiarów czujników i elementów wykonawczych generujących sygnały zmieniające się dynamicznie podczas pracy silnika.

Badania przeprowadzano z użyciem odpowiedniej aparatury pomiarowej, między innymi oscyloskopu AOC1K (rejestratora cyfrowego, współpracującego z komputerem PC przez interfejs RS232) i komputera PC.

Obiektem badań były samochody wyposażone w system Simos 2P (Siemens):

1. Skoda Felicia 1.3 MPI hatchback, rok produkcji - 1998; przebieg - 220 tys. km, w tym 100 tys. $\mathrm{km}$ - zasilanie benzyną bezołowiową LO 95 oraz 120 tys. $\mathrm{km}$ - zasilanie gazem LPG; obsługi techniczne zgodnie z wymogami producenta.

2. Skoda Felicia 1.3 MPI pickup, rok produkcji - 1997; przebieg - 70 tys. $\mathrm{km}$ - zasilanie benzyną bezołowiową LO 95; obsługi techniczne zgodnie z wymogami producenta; w trakcie eksploatacji stwierdzono uszkodzenie mechaniczne wtryskiwaczy paliwa oraz zwiększenie toksyczności spalin.

Badania czujników oraz urządzeń wykonawczych systemu sterowania pracą silnika należy poprzedzić oględzinami i oceną stanu technicznego przewodów (ewentualne przetarcia, zerwania) oraz konektorów łączących wiązki przewodów z urządzeniami, w celu wykluczenia zwarć do masy lub do plusa, ewentualnie pomiędzy przewodami tej samej wiązki przewodów. Szczególną uwagę należy zwrócić na zanieczyszczenia występujące na konektorach, mogące powodować zwiększenie rezystancji na złączu lub całkowite przerwanie obwodu.

Bardzo istotne jest sprawdzenie poprawności działania układu paliwowego: kontrola przekaźnika pompy paliwa, pompy paliwa, szczelności oraz drożności elementów hydraulicznych układu.

Pomiary sygnałów na stykach elektronicznego urządzenia sterującego (Simos 2P) (ECM - engine control module) obejmują procedury pomiarowe dla poszczególnych sygnałów, zgodnie z oznaczeniem styków. Pomiary ułatwia skrzynka pomiarowa (adapter) włączana pomiędzy urządzenie a wiązkę przewodów. W sytuacji braku adaptera, 
urements are facilitated by means of the measuring box (adapter) incorporated between the device and wire assembly. In case of lacking adapter, a special probe penetrating through the conductors (invasive method) should be used. The values of voltages shall conform with those specified in the servicing manual. In case of voltages different from service voltages, check the cabling and fuses.

After completed tests, the error codes memory in engine control module shall be cleared.

The examinations of Hall-effect based CMP - camshaft position sensor and RPM - engine speed sensor consist in checking of the sensor supply voltage and in recording of the signal generated by the operating sensor. Refer to Fig. 1 for illustration of the record representing a rectangular pulse

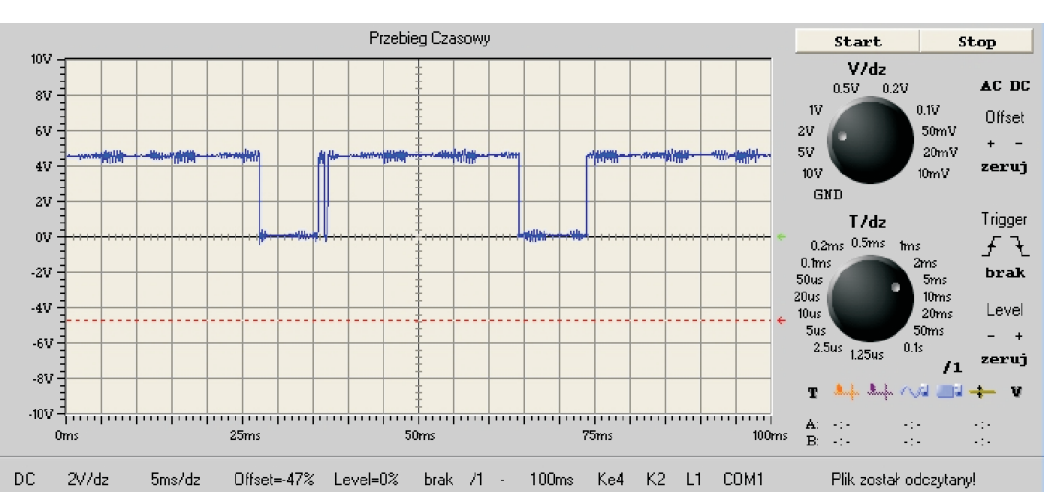

Fig. 1. Incorrect signal of the speed sensor

Rys.1. Nieprawidłowy sygnał czujnika prędkości obrotowej

incorporating voltage peaks up to $4.4 \mathrm{~V}$ corresponding to the proximity between the sensor and magnets incorporated on the flywheel. Insignificant signal oscillations visible on horizontal lines of the representation were resulted from the material fragments separated from rotating magnets and deposited on metal element of the sensor. Such situation caused the disturbances in correct interpretation of the signal by the engine control module and could be a potential reason of the disturbances in uniform engine operation in particular circumstances.

The measurements of the signals on lambda probe contacts with heater lambda probe $(\mathrm{HO} 2 \mathrm{~S}$ - heated oxygen sensor) encompass the measurement procedures for individual signals using the contacts symbols in accordance with the documentation. Prior to starting the measurements, the probe heater should be checked for correct operation.

The lambda probe signal checking is carried out after the achievement of the operation temperature by engine. The signal generated by a new correctly operating probe at the speed of $2000 \mathrm{rpm}$ is illustrated in Fig. 2. The frequency of probe signal oscillations is equal to about $1.5 \mathrm{~Hz}$.

The lambda probe operates in feedback mode; therefore its signal is similar należy użyć specjalną sondę przebijającą przewody (metoda inwazyjna). Wartości napięć powinny być zgodne z wartościami podanymi w instrukcji serwisowej. Jeżeli napięcia są inne niż wartości serwisowe, należy sprawdzić okablowanie oraz bezpieczniki.

Po wykonaniu badań należy wykasować pamięć kodów błędów z urządzenia sterującego silnikiem.

Badania czujnika położenia i prędkości obrotowej wału korbowego (CMP - camshaft position sensor) (RPM - engine speed sensor) (hallotronowy) sprowadzają się do sprawdzenia napięcia zasilania czujnika oraz zarejestrowania sygnału pochodzącego od pracującego czujnika. Zarejestrowany przebieg przedstawiono na rys. 1 . Widoczny jest sygnał prostokątny, w którym skoki napięcia do 4,4 V odpowiadają ,napotkaniu” czujnika przez naklejone na kole zamachowym wirujące magnesy. Niewielkie oscylacje sygnału na poziomych liniach przebiegu były spowodowane osadzeniem się na elemencie metalowym czujnika fragmentów materiału oderwanego od wirujących magnesów. Sytuacja taka powodowała zakłócenia w poprawności interpretacji sygnałów przez urządzenie sterujące, a w szczególnym przypadku mogła spowodować zakłócenia w równomierności pracy silnika.

Pomiary sygnałów na stykach sondy lambda z grzałką sondy lambda $(\mathrm{HO} 2 \mathrm{~S}-$ heated oxygen sensor) obejmują procedury pomiarowe dla poszczególnych sygnałów przy wykorzystaniu oznaczeń styków zgodnie z dokumentacją. Przed przystąpieniem do pomiarów należy sprawdzić poprawność działania grzałki sondy.

Sprawdzenie sygnału sondy lambda przeprowadza się po osiągnięciu przez silnik temperatury eksploatacyjnej. Na rysunku 2 przedstawiono sygnał nowej, poprawnie działającej sondy przy $2000 \mathrm{obr} / \mathrm{min}$. Sygnał sondy oscyluje z częstotliwością około 1,5 Hz.

Sonda lambda pracuje w sprzężeniu zwrotnym, zatem jej sygnał zbliżony jest do nieregularnej sinusoidy, której częstotliwość zmian powinna zawierać się w granicach od $0,5 \mathrm{~Hz}$ na biegu jałowym do $4 \mathrm{~Hz}$ przy prędkości obrotowej

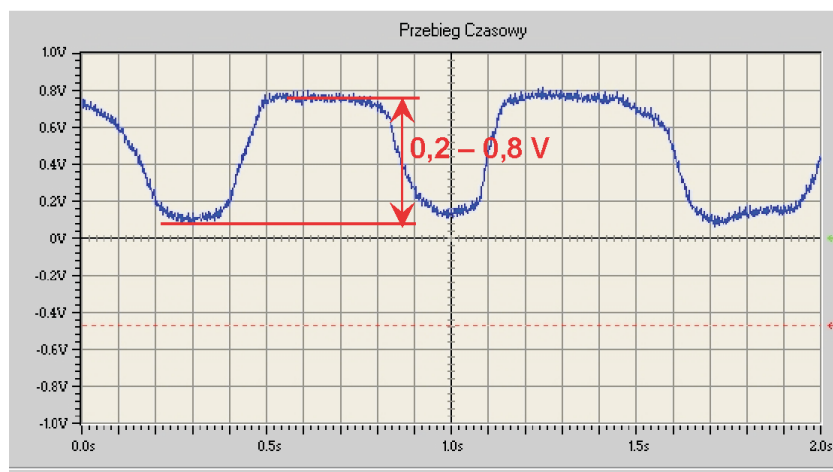

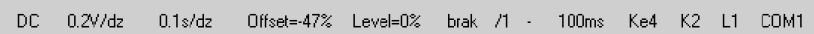

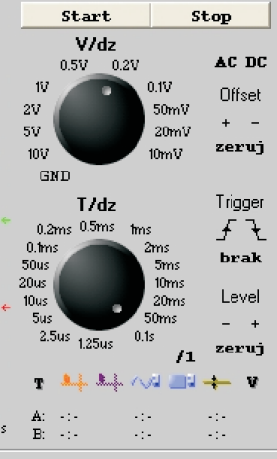

Flik: został adczylany!

Fig. 2. Correct signal of lambda probe (for engine speed of $2000 \mathrm{rpm}$ )

Rys. 2. Prawidtowy sygnat sondy lambda (dla prędkości obrotowej silnika $2000 \mathrm{obr} / \mathrm{min}$ ) 


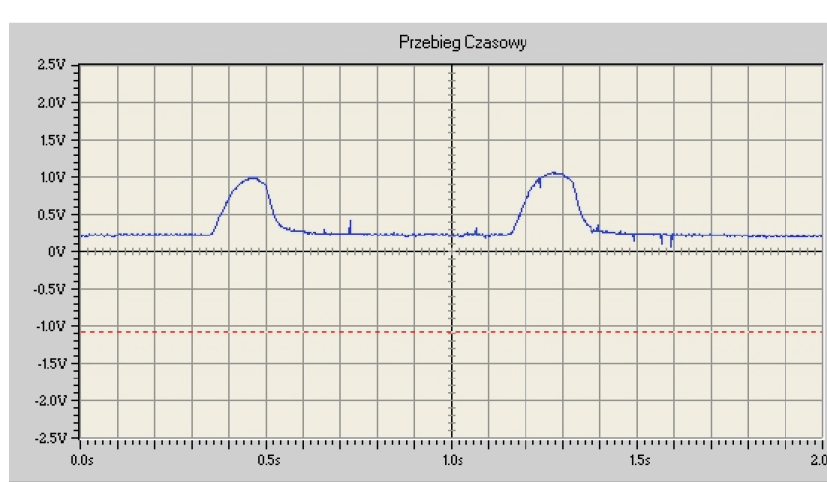

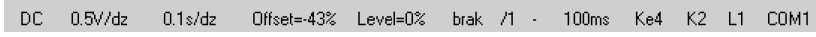

Fig. 3. Incorrect signal of the lambda probe Rys. 3. Nieprawidłowy sygnat sondy lambda

to an irregular sinusoid with variations frequency to be included between $0,5 \mathrm{~Hz}$ on idling and $4 \mathrm{~Hz}$ for engine speed of about $4000 \mathrm{rpm}$. The lambda probe signal illustrated in Fig. 3 is incorrect. The probe is inactive, some characteristic rises visible in the oscillogram were produced in the result of a momentary increase of the engine speed from 1000 to $4000 \mathrm{rpm}$, but any sinusoid characterizing the lambda probe is invisible in the further part of the diagram.

After long term operation, particularly in extreme conditions, for instance in case of damage occurred in engine control module or engine running on LPG, the lambda probe is subject to natural ageing manifesting itself in the form of gradually reduced operation frequency. Such circumstances are usually not detectable by means diagnostic testers, but can be indicated by increased content of toxic compounds in exhaust gases. However the correct diagnosis for lambda probe is possible by means of an oscilloscope only.

The measurements of the signals on the air suction pressure sensor contacts (MAP - manifold absolute pressure sensor) encompass the measurement procedures for individual signals using the contacts symbols in accordance with documentation. The values of supply voltages are checked after the ignition switching

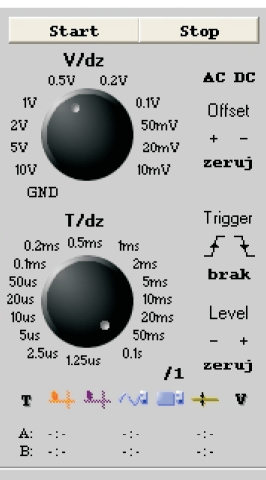

Plik zostat odczytany!

silnika około 4000 obr/min. Na rysunku 3 przedstawiono nieprawidłowy sygnał z sondy lambda. Sonda nie pracuje, widoczne na oscylogramie charakterystyczne wzniesienia powstały w wyniku chwilowego zwiększenia prędkości obrotowej silnika z 1000 do 4000 obr/min, natomiast w dalszej części wykresu nie stwierdza się charakterystycznej dla sondy lambda sinusoidy.

Sonda poddana długotrwałej eksploatacji, a szczególnie w warunkach ekstremalnych, jak na przykład awarie w układzie sterowania silnikiem, bądź zasilanie silnika gazem LPG, ulega naturalnemu starzeniu, co objawia się stopniowym zmniejszaniem częstotliwości pracy. Taki stan zazwyczaj nie jest wykrywalny przez testery diagnostyczne. $\mathrm{Na}$ zaistniałą sytuację może wskazywać zwiększona ilość toksycznych związków w spalinach, jednak właściwą diagnozę sondy lambda można przeprowadzić tylko za pomocą oscyloskopu.

Pomiary sygnalów na stykach czujnika ciśnienia powietrza dolotowego (MAP - manifold absolute pressure sensor) obejmują procedury pomiarowe dla poszczególnych sygnałów przy wykorzystaniu oznaczeń styków zgodnie z dokumentacją. Napięcia zasilania sprawdza się po wyłą-

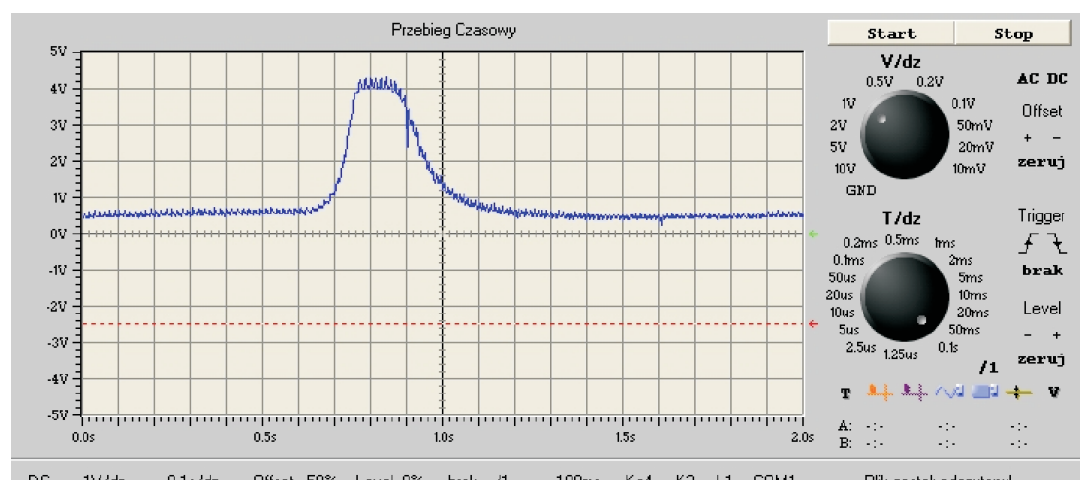

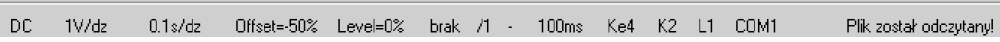

Fig. 5. Incorrect signal of the air suction pressure sensor

Rys. 5. Nieprawidłowy sygnał czujnika ciśnienia powietrza dolotowego

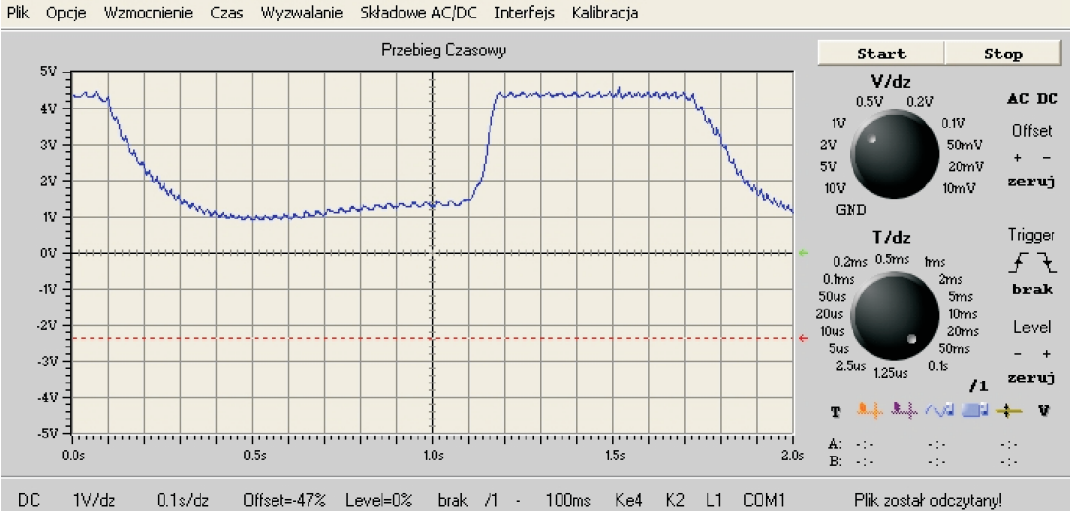

Fig. 4. Correct signal of the air suction pressure sensor

Pawidtowy sygnał czujnika ciśnienia powietrza dolotowego

czeniu zapłonu pomiędzy odpowiednimi złączami wiązki zasilającej. Napięcie to powinno wynosić $5 \mathrm{~V}$.

Rejestrację przebiegu sygnału przeprowadza się po podłączeniu sondy oscyloskopu do odpowiedniego złącza wiązki zasilającej czujnik po uruchomieniu silnika. Na rysunku 4 przedstawiono zarejestrowany przebieg sygnału czujnika ciśnienia powietrza dolotowego.

$\mathrm{Na}$ rysunku 5 przedstawiono zarejestrowany sygnał uszkodzonego czujnika ciśnienia. 
OFF between corresponding connectors of the power supply wire assembly. The voltage shall be equal to $5 \mathrm{~V}$. The signal is recorded after the connection of the oscilloscope probe to the corresponding connector of the wire assembly supplying the sensor after engine starting. Refer to Fig. 4 for the representation of recorded signal of the air suction pressure sensor and to Figure 5 for the representation of recorded signal of a damaged pressure sensor.

The measurements of the signals on the throttle position sensor contacts (throttle actuator potentiometer) ( $\mathbf{T P}$ - throttle position sensor) encompass the measurement procedures for individual signals using the contacts symbols in accordance with documentation. The value of supply voltage is checked between corresponding connectors of the power supply wire assembly after the ignition switching ON. The voltage shall be equal to $5 \mathrm{~V}$. The sensor signal is checked after the connection of oscilloscope probe to the corresponding connector of wire assembly supplying to sensor with throttle open and closed..

Refer to Fig. 6 for the representation of the signal obtained from the throttle position sensor. The oscilloscope signal should not be interrupted along its whole length (local voltage drops to $1,2 \mathrm{~V}$ in course of acceleration - local voltage drops would be the symptoms of discontinuities on the resistance element of the sensor).

The measurements of the signals on the contacts of idle speed control actuator unit (throttle actuator) (ISC idle speed control actuator position sensor) encompass the measurement procedures for individual signals using the contacts symbols in accordance with documentation.

The signal is checked after the connection of oscilloscope probe to the corresponding connector of wire assembly supplying to throttle actuator and after the engine starting.

The signal displayed on the oscilloscope should encompass the voltage pulses on the ends pf rectangular pulse (Fig. 7) originating from the throttle actuator windings inductivity and demonstrating the winding continuity i.e. the correct operation of the throttle actuator motor.

The measurements of the signals on the contacts of knock sensor (KS) encompass the measurement procedures for individual signals using the contacts symbols in accordance with documentation.

The measurement procedure (resistance checking) to carried out after the sensor removal, encompasses the checking if the engine block and the sensor surface are free of corrosion, otherwise the surfaces should be cleaned thoroughly. Then the sensor should be installed and tightened with correct torque. The resistance is checked between the connectors of the sensor. Its value should be infinitely high.

The measurement signal is checked after the connection of oscilloscope probe and af-
Pomiary sygnałów na stykach czujnika położenia przepustnicy (potencjometru nastawnika przepustnicy) (TP - throttle position sensor) obejmują procedury pomiarowe dla poszczególnych sygnałów przy wykorzystaniu oznaczeń styków zgodnie z dokumentacją. Sprawdzenie napięcia zasilania przeprowadza się między odpowiednimi złączami wiązki zasilającej po włączeniu zapłonu. Powinno ono

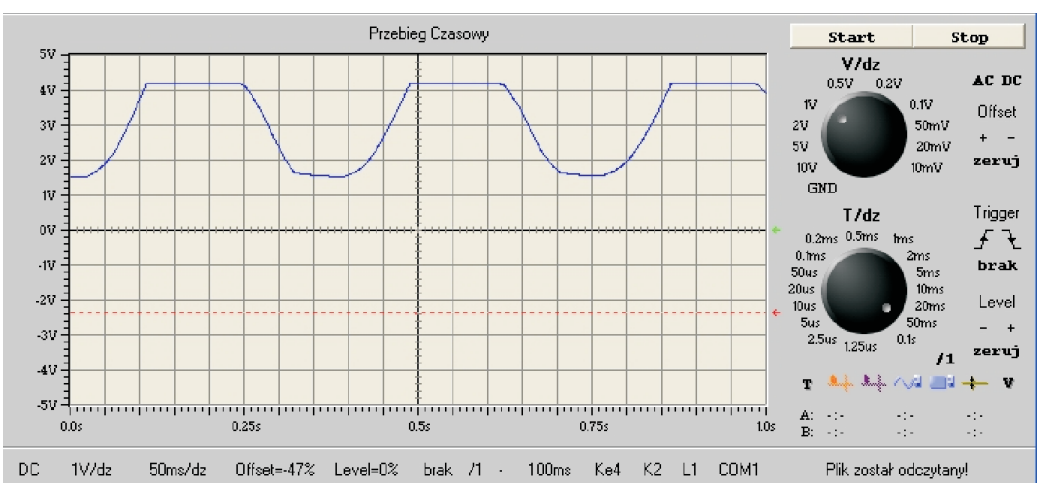

Fig. 6. Correct signal of the throttle position sensor Rys. 6. Prawidłowy sygnat czujnika położenia przepustnicy

wynosić 5 V. Sprawdzenie sygnału czujnika przeprowadza się po podłączeniu sondy oscyloskopu do odpowiedniego złącza wiązki zasilającej czujnika, przy otwartej i zamkniętej przepustnicy. Na rysunku 6 przedstawiono otrzymany przebieg sygnału z czujnika położenia przepustnicy. Przebieg sygnału oscyloskopowego nie powinien być na całej długości przerwany (miejscowe spadki napięcia do 1,2 V podczas przyspieszania - miejscowe spadki napięcia świadczyłyby o przerwach na elemencie oporowym czujnika).

Pomiary sygnałów na stykach zespołu regulatora biegu jałowego (nastawnika przepustnicy) (ISC - idle speed control actuator position sensor) obejmują procedury pomiarowe poszczególnych sygnałów przy wykorzystaniu oznaczeń styków zgodnie z dokumentacją.

Sprawdzenie sygnału przeprowadza się po podłączeniu sondy oscyloskopu do odpowiedniego złącza wiązki zasilającej nastawnika i uruchomieniu silnika.

Przebieg sygnału oscyloskopowego powinien mieć na końcach sygnału prostokątnego (rys. 7) impulsy napięciowe pochodzące od indukcyjności uzwojenia nastawnika, świad-

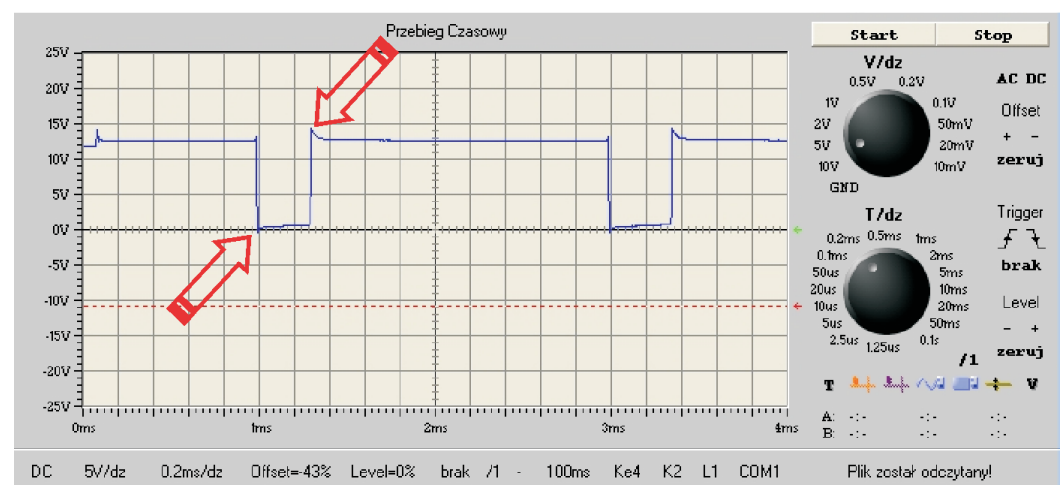

Fig. 7. Correct signal of the throttle actuator Rys. 7. Prawidłowy sygnat nastawnika przepustnicy 


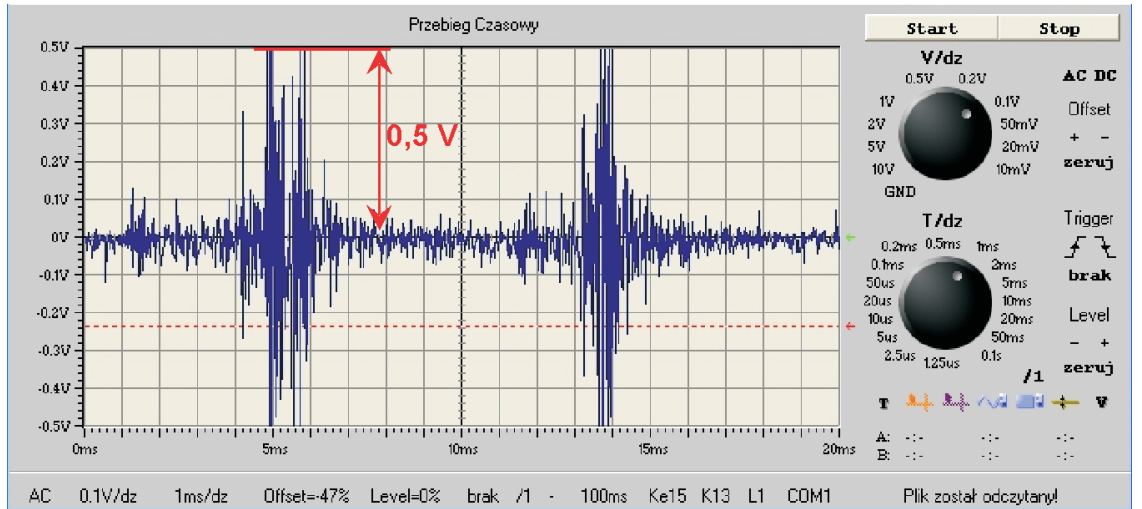

Fig. 8. Correct signal of the knock sensor $(20 \mathrm{~N} \cdot \mathrm{m})$ Rys. 8. Prawidłowy sygnat czujnika spalania stukowego $(20 \mathrm{~N} \cdot \mathrm{m})$ czące o braku przerw w uzwojeniu, a zatem poprawności działania silnika nastawnika przepustnicy.

Pomiary sygnałów na stykach czujnika spalania stukowego (KS - knock sensor) obejmują procedury pomiarowe dla poszczególnych sygnałów przy wykorzystaniu oznaczeń końcówek zgodnie z dokumentacją.

Procedura pomiarowa (sprawdzenie rezystancji) obejmuje po zdemontowaniu czujnika sprawdzenie, czy blok silnika oraz powierzchnia czujnika są wolne od korozji; jeżeli nie - należy

ter the engine starting. Refer to Fig. 8 for the representation of the signal from the sensor installed correctly (tightened with the torque of $20 \mathrm{~N} \cdot \mathrm{m}$ in accordance with the procedure) properly pressed to the surface of engine block. The voltage of $0.5 \mathrm{~V}$ is reached at vibration amplitude.

A damage in the form of improper contact between the sensor plane and the engine block plane has been simulated in the course of the measurement of the signal from the knock sensor. Such situation can occur in case of oxidation of the adhering surfaces or in case of incidental loos-

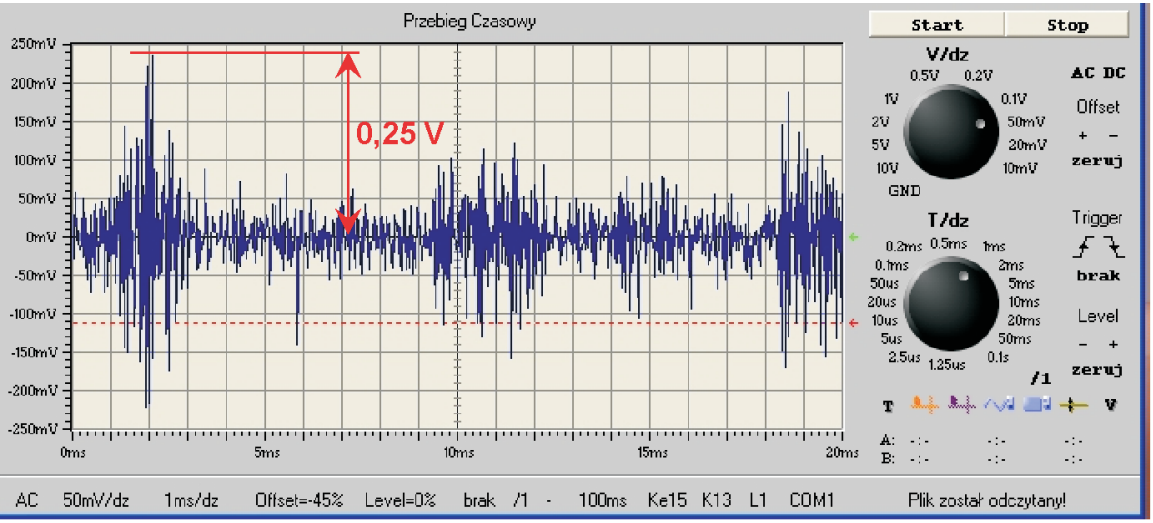

Fig. 9. Incorrect signal of the knock sensor $(10 \mathrm{~N} \cdot \mathrm{m})$

Rys. 9. Nieprawidłowy sygnat czujnika spalania stukowego $(10 \mathrm{~N} \cdot \mathrm{m})$ ening of the sensor fastening bolt or in case of sensor tightened with incorrect torque. Improper contact of the sensor results in the errors in dynamic control of the ignition advance angle. Refer to Fig. 9 for the representation of the signal from the sensor tightened with the torque lower than its expected value i.e. $10 \mathrm{~N} \cdot \mathrm{m}-$ the signal amplitude is equal to $0.25 \mathrm{~V}$ in this case.

Refer to Fig. 10 representing the sensor tightened with the torque of about $2 \mathrm{~N} \cdot \mathrm{m}$. The signal transmitted from the sensor is almost undetectable, its amplitude oscillates within 0.05

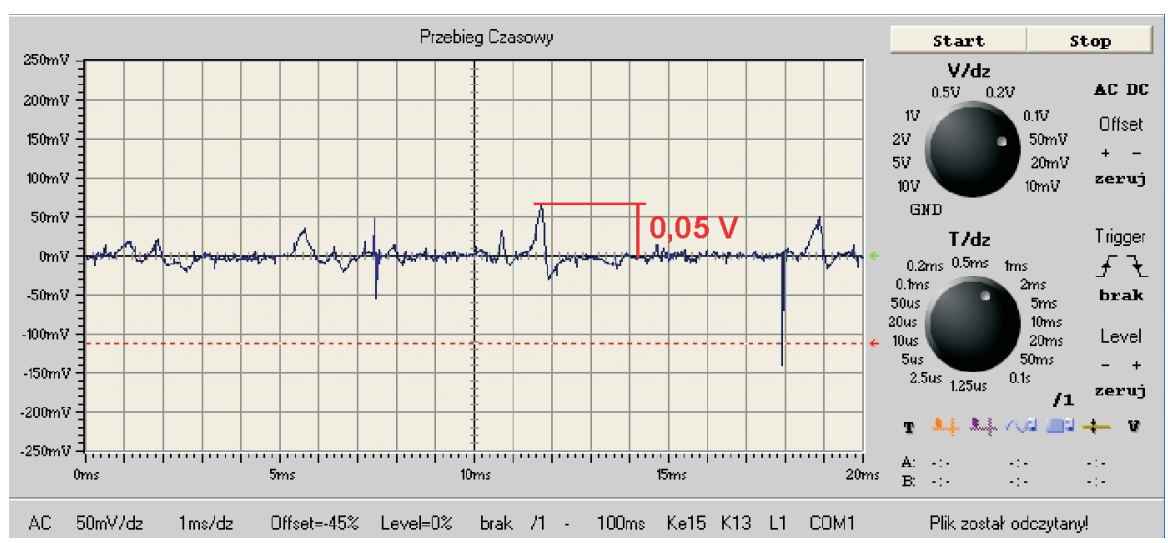

Fig. 10. Incorrect signal of the knock sensor $(2 \mathrm{~N} \cdot \mathrm{m})$ Rys. 10. Nieprawidtowy sygnat czujnika spalania stukowego $(2 \mathrm{~N} \cdot \mathrm{m})$ dokładnie oczyścić powierzchnie. Następnie należy zamontować czujnik i dokręcić go właściwym momentem. Rezystancję sprawdza się pomiędzy złączami czujnika. Jej wartość powinna być nieskończenie duża.

Sprawdzenie sygnału pomiarowego dokonuje się po podłączeniu sondy oscyloskopu i po uruchomieniu silnika. $\mathrm{Na}$ rysunku 8 przedstawiono zarejestrowany sygnał z czujnika właściwie zamontowanego (zgodnie z procedurą momentem $20 \mathrm{~N} \cdot \mathrm{m}$ ) mającego właściwy docisk do powierzchni bloku silnika. Napięcie amplitudy drgań sięga $0,5 \mathrm{~V}$.

Dokonując pomiaru sygnału z czujnika spalania stukowego, symulowano uszkodzenia $\mathrm{w}$ postaci niewłaściwego przylegania płaszczyzny czujnika do płaszczyzny bloku silnika. Taka sytuacja może zaistnieć w przypadku utlenienia się powierzchni przylegających lub samoistnego odkręcenia się śruby mocującej czujnik, jak również dokręcenia czujnika niewłaściwym momentem. Niepoprawne przyleganie czujnika powoduje błędy w dynamicznej regulacji kąta wyprzedzenia zapłonu. Na rysunku 9 przedstawiono sygnał 
V. Therefore any correct information about the combustion processes occurring in the engine are unavailable.

\section{Conclusions}

The electronic devices installed in the vehicle must be subject to periodical diagnostic tests in order to ensure their correct operation and to perform their tasks. The diagnostic tester is capable to detect the error codes. Nevertheless the experience of diagnostic engineer and the use of other methods i.e. oscilloscope tests make it possible to precisely determine the damage.

Unless any parameters are not determined by the manufacturer for the signals obtained from the sensors, the correct air-fuel mixture usually can not be controlled properly, the engine performance is reduced and the content of toxic compounds of the exhaust gases is increased.

As an example which has been confirmed in our experimental tests, is ,the behaviour" of lambda probe which has been operated in the testing object during the whole operation mileage of the vehicle $(220,000 \mathrm{~km})$ and has been exposed to extremely difficult operation conditions resulting from running on LPG. The difficult operation conditions resulted in prematurely "aged" probe which is demonstrated by the reduced frequency of its operation. Analogical disturbances have been detected in other sensors which could not be identified in the form of the error codes.

Artykut recenzowany czujnika dokręconego momentem o połowę mniejszym od przewidywanego, tj. $10 \mathrm{~N} \cdot \mathrm{m}$ - amplituda sygnału $\mathrm{w}$ tym przypadku wynosi $0,25 \mathrm{~V}$.

Na rysunku 10 przedstawiono przypadek dokręcenia czujnika momentem około $2 \mathrm{~N} \cdot \mathrm{m}$. Sygnał przekazywany z czujnika jest niemal niewykrywalny, jego amplituda oscyluje w granicach $0,05 \mathrm{~V}$, co nie zapewnia właściwego przekazu informacji o zachodzących w silniku procesach spalania.

\section{Podsumowanie}

Urządzenia elektroniczne w pojeździe, aby mogły właściwie działać i wypełniać wszystkie powierzone zadania, muszą podlegać okresowym badaniom diagnostycznym. Tester diagnostyczny jest w stanie wykryć wiele usterek, jednak doświadczenie diagnosty oraz zastosowanie innych metod, takich jak badania oscyloskopowe, zapewnia ustalenie uszkodzenia.

Jeżeli sygnały z czujników nie mają określonych przez producenta parametrów, najczęściej nie zapewniają właściwej regulacji składu mieszanki, spadają osiągi silnika i następuje wzrost emisji toksycznych składników spalin do atmosfery. Przykładem, który potwierdził się w badaniach eksperymentalnych jest ,zachowanie się” sondy lambda, która w obiekcie badań była przez cały przebieg eksploatacyjny pojazdu (220 tys. $\mathrm{km}$ ) oraz była narażona na ekstremalne warunki eksploatacji spowodowane zasilaniem silnika gazem LPG. Trudne warunki eksploatacji spowodowały szybsze zużycie, tzw. ,zestarzenie” się sondy, co objawia się obniżoną częstotliwością jej pracy. Analogiczne nieprawidłowości w działaniu stwierdzono w innych czujnikach.

\section{Bibliography/Literatura}

[1] Burdka M.: Oscyloskop w diagnostyce samochodowej. Instalator Polski. Warszawa 2002.

[2] Cedrych M.R.: Skoda Felicia, WKiŁ, Warszawa 1996.

[3] Cedrych M.R., Schwarz J.: Skoda Fabia. WKiŁ, Warszawa 2002.

[4] Dziubiński M.: Elektroniczne układy pojazdów samochodowych. Wydawnictwo Naukowe Gabriel Borowski, Lublin 2004.

[5] Dziubiński M.: Badania elektronicznych urządzeń pojazdów samochodowych. Wydawnictwo Naukowe Gabriel Borowski, Lublin 2004.

Prof. Wiktor Pietrzyk, DSc, MEng - professor in the Faculty of Electrical Engineering and Computer Science, Department of Computer and Electrical Engineering, Lublin University of Technology. Prof. zw. dr hab. inz. Wiktor Pietrzyk - profesor na Wydziale Elektrotechniki i Informatyki Politechniki Lubelskiej, kierownik Katedry Inżynierii Komputerowej i Elektrycznej.
[6] Wiśniewski S.: Badania eksperymentalne wyposażenia elektrycznego samochodu Skoda. Praca dyplomowa. Lublin 2007.

[7] Autodata-CD 2.12.

Mr Mieczysław Dziubiński, PhD, MEng - Lublin University of Technology, Faculty of Mechanical Engineering, Departmend of Automotive Vehicles. Dr inż. Mieczysław Dziubiński - st. wykładowca w Katedrze Pojazdów Samochodowych na Wydziale Mechanicznym Politechniki Lubelskiej.

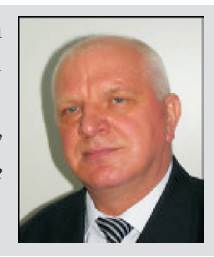

Mr Stanisław Walusiak, PhD, MEng - Lublin University of Technology, Faculty of Electrical Engineering and Computer Science, Department of Computer and Electrical Engineering.

Dr inż. Stanistaw Walusiak - st. wykladowca w Katedrze Inżynierii Komputerowej i Elektrycznej na Wydziale Elektrotechniki i Informatyki Politechniki Lubelskiej. 